TITLE:

ON THE IDENTIFICATION AND THE AFFINITY OF TAMANOVALVA LIMAX, A BIVALVED SACOGLOSSAN MOLLUSC IN JAPAN

$\operatorname{AUTHOR}(\mathrm{S})$ :

Baba, Kikutaro

CITATION:

Baba, Kikutaro. ON THE IDENTIFICATION AND THE AFFINITY OF TAMANOVALVA LIMAX, A BIVALVED SACOGLOSSAN MOLLUSC IN JAPAN. PUBLICATIONS OF THE SETO MARINE BIOLOGICAL LABORATORY 1961, 9(1): 37-62

ISSUE DATE:

1961-05-30

URL:

http://hdl.handle.net/2433/174663

RIGHT: 


\title{
ON THE IDENTIFICATION AND THE AFFINITY OF TAMANOVALVA LIMAX, A BIVALVED SACOGLOSSAN MOLLUSC IN JAPAN ${ }^{13}$
}

\author{
KIKUTARÓ BABA \\ Biological Laboratory, Osaka Gakugei University
}

With Plates I-IV and 3 Text-figures

Just after the publication of the preliminary note on a bivalved sacoglossan, Tamanovalva limax KAwAGUTI \& BABA, 1959, I was advised by Dr. Tokubei KURODA of the Kyoto University to identify Tamanovalva again with the questioned bivalve Edenttellina. He was kind enough to take pains in obtaining some necessary literature (GatlifF \& Gabriel, 1911; Hedley, 1912, 1920; Cotton \& Godfrey, 1938, etc.) from his private library and from the Kyoto University libraries in the interest of my treatise. Reference to Verco's (1911, 1916) was made possible by the courtesy of Mr. Robert Burn in Australia. During this time, I was called attention by Drs. L. R. Cox and W. J. Rees (1960) of the British Museum to the similarity of Tamanovalva with Edenttellina and with the Parisian fossil bivalve Ludovicia (see also HedLey, 1912). Also I was asked by Dr. Myra KeEN (1960a, 1960b) of the Stanford University to go further to identify Tamanovalva with Berthelinia, known as an embryonic gastropod shell from the Paris Basin. There arose thus a Tamanovalva-Edenttellina-LudoviciaBerthelinia connection which awaited thorough revision ${ }^{2)}$. I am greatly indebted to Drs. L. R. Cox and W. J. ReEs who have kindly sent me the copied text of the "catalogue" by Cossmann, 1888. In referring to Cossmann, I owe much also to Dr. Myra KEEN.

Thanks to Dr. Tadashige HABE of the Amakusa Marine Biological Laboratory,

1) Contributions from the Tamano Marine Laboratory, No. 82.

2) Before the completion of the present paper, an essay by Mr. R. BURN (1960b) has been sent me announcing the synonymy of Tamanovalva with Edenttellina, and the creation of a new genus Midorigai from Victoria (see also BURN, 1960a). Previous to this, I was told by a letter from Dr. Myra KeEN of her success in collecting a living bivalved sacoglossan from the Gulf of California in August, 1960. Also it is said that a fossil species of the sacoglossan bivalves was obtained from South Australia by Dr. N. H. Ludbrook and Mr. T. M. STEEeL in 1960 (by letters from Dr. LUDBROOK and Mr. BURN).

Publ. Seto Mar. Biol. Lab., IX (1), 1961. (Article 4) 
I was able to make a bibliographical review of the primitive sacoglossan genus Arthessa.

Specimens of Tamanovalva employed in the present study have been obtained mainly from the Inland Sea of Seto, Japan (Tamano, Aug. 1959; Aug. 1960; Mar. 1961 ; Mukaishima, Mar. and June 1960) ; partly from the Toyama Bay, Japan Sea (Abugashima, Aug. 1959; Aug. 1960). Willing cooperations for collecting were afforded by Dr. Siro KawaGuTi (Tamano Marine Laboratory), Dr. Akihiko INABA (Mukaishima Marine Biological Station) and Mr. Takeo ABE (Takaoka Senior High School, Toyama Pref.).

For the aim of the comparative anatomy, the following genera and species have especially been taken into consideration ${ }^{1)}$ :

1. Edenttellina typica GATIIFF \& GABRIEL, 1911.

Flinders, Victoria, Mar. 1960, $1 \mathrm{sp}$. (shell-length $2.5 \mathrm{~mm}$ ), presented by Mr. BurN, designated at first as Midorigai australis "paratype", but later suggested to be the above species.

2. Oxynoe viridis (PEASE, 1861).

Misaki, Sagami Bay, Aug. 1951, 3 sps. (total length of animal $25 \mathrm{~mm}$ ), presented by His Majesty's Biological Laboratory; Abugashima, Toyama Bay, Aug. 1954, 1 sp. (total length $18 \mathrm{~mm}$ ), presented by Mr. ABE. See BABA, 1952a, 1955.

3. Lobiger sagamiensis BABA, 1952.

Misaki, Sagami Bay, Aug. 1951, 3 sps. (total length $10 \mathrm{~mm}$ ), presented by His Majesty's Biological Laboratory. See BABA, 1952b, 1955.

The presentation of this paper in the printed form is due to Dr. Huzio UTINom of the Seto Marine Biological Laboratory.

I wish to express my cordial thanks to all who have helped me in various ways.

\section{Review of the Previous Records}

The following is a list of genera and species considered to be in close connection with each other:

1) A comparative study has also been made on the species and subspecies listed below, the actual specimens of which being offered me for exchange.

1. Berthelinia typica BuRN, 1960 (non Edenttellina typica GATLIFF \& GABRIEL, 1911).

Torquay, Victoria, Mar. 1960, $1 \mathrm{sp}$. (shell-length $4 \mathrm{~mm}$ ), collected by Mr. BurN. See BURN, 1960a, 1960b.

2. Midorigai australis BURN, 1960.

Torquay, Victoria, Nov. 1960, 8 sps. (shell-length 1-4.6 mm), collected by Mr. BuRN. See BURN, 1960a, 1960b.

3. Berthelinia chloris (DALL, 1918), subspecies.

Espiritu Santo I., Gulf of California, Dec. 1960, 2 sps. (shell-length 4.5-7 mm), collected by Dr. KEeN. See KeEN, 1960b. 
1. Berthelinia $\mathrm{C}_{\mathrm{ROSSE}}, \mathbf{1 8 7 5 .}$

$\dagger$ B. elegans $\mathrm{C}_{\mathrm{ROSSE}}$, 1875. Paris Basin Eocene (Courtagnon). A single left valve (P1. I, figs. 14A-14B).

$\dagger$ B. elegans [?] by CROsse \& Fischer, 1887. Paris Basin Eocene (Le Ruel, etc.). Left and right valves (Pl. I, figs. 15A-15B).

$\dagger$ B. elegans [?] by Cossmann, 1888. Paris Basin Eocene (Château-Rouge). Right valve (Pl. I, figs. 16A-16B).

$\dagger$ B. elegans [?], var. elata Cossmann, 1888. Paris Basin Eocene (Le Ruel). Left and right valves (Pl. I, figs. 17A-17B).

The shell of the genotype is $0.5 \mathrm{~mm}$ long, and, as a developmental stage, it corresponds roughly to the youngest adult form of Tamanovalva (see KAwAGUTI, 1959, p. 610 , figs. $7 \mathrm{a}-7 \mathrm{c}$; see also Text-fig. 2, B-D). The coil of the protoconch in the genotype is said to consist of 2 whorls; the matured shell, which must be differentiated more, was not traced originally.

2. Ludovicia Cossmann, 1888.

$\dagger$ L. squamula Cossmann, 1888. Paris Basin Eocene (Parnes). Left and right valves ( $\mathrm{Pl}$. I, figs. $18 \mathrm{~A}-18 \mathrm{~B}$ ).

The shell is exceedingly large (twice as large as the biggest shell of Tamanovalva); moreover, it may be added that this is "very inequilateral, highly dilated in front, obtuse behind, and provided with a small protoconch at the latter one-fourth of the shell-length".

3. (?) Anomalomya Cossmann, 1888.

$\dagger$ A. corrugata CossmanN, 1888. Paris Basin Eocene (Le Fayel). A single right valve (Pl. I, figs. 19A-19B). Protoconch unknown.

4. Edenttellina Gatliff \& Gabriel, $1911^{1)}$.

E. typica Gatliff \& Gabriel, 1911. Victoria (Port Sea, etc.). Left and right valves (Pl. I, figs. 20A-20B).

E. typica [?] by Verco, 1916. South Australia (Guichen Bay), in shell sand. Left and right valves.

E. typica [?] by Hedley, 1920.

E. typica [?] by CotTon \& Godfrey, 1938.

E. typica [?] by BuRn, 1960a. Victoria (Torquay). Living animals on Caulerpa.

Berthelinia typica (?) by BuRn, 1960b.

E. corallensis HedLey, 1920. North Queensland, in 5-10 fms. coral mud. Left and right valves (Pl. I, figs. 21A-21B).

Originally the shell of the genotype is shown thus (summarized): "Shell

1) See the comment by Hedley, 1912. 
$3 \mathrm{~mm}$ long, flattened, broadly ovate, very inequilateral, anterior side somewhat swollen; slightly convex, yellow ; incurved protoconch of a rounded form, coiled, overlapping the right valve; hinge-line without teeth". The annexed figures show that the shell is abruptly rounded behind, and the protoconch marks its position at the latter one-fourth of the shell-length (cf. Ludovicia).

E. typica Verco (and HedLeY) differs from the genotype as follows: (1) the shell is markedly narrowed posteriorly, and (2) the protoconch, seemingly large in size, coiled in 2 whorls, and standing erect, is found at the latter one-third of the shell-length. E. corallensis HEDLEY is separated from typica Verco (and HEDLEY) by having the shell "more solid, more compressed, and more pointed posteriorly" than in the latter species. Unfortunately the protoconch in corallensis was not shown in detail. E. typica Cotton \& Godfrey is the union of two different species, the genotype and typica Verco (and HedLeY). E. typica BURN comes to be re-identified.

5. Tamanovalva KAWAGUTI \& BABA, 1959.

T. limax KawaGuti \& BabA, 1959. Japan.

6. Midorigai BuRN, 1960.

M. australis BuRN, 1960, "holotype". Victoria (Torquay). Living animals on Caulerpa.

\section{The Comparative Anatomy of Tamanovalva limax}

The Shell: In Tamanovalva the shell is bivalved, the bipartition of a shell taking place during metamorphosis (KawaGUTI, 1959) ${ }^{1}$. The two valves when completed are almost equal in size, shape and convexity; they are extremely thin and fragile (Text-fig. 1, B; Pl. I, figs. 1A-1B, 2A-2B). The periostracum is colourless, the pearl layer is shiny, and the intermediate calcareous layer assumes a faint tinge of green; the general colour effect of the hyaline shell is pale yellowish green or yellowish white in different specimens. Sometimes there are traces of radiating, obscure bands of yellow on the shell. The maximum size of the full-grown shell is about $8 \mathrm{~mm}$ long, $5.5 \mathrm{~mm}$ high and $2.5 \mathrm{~mm}$ broad. The helicoid protoconch at the apex of the left valve is porcelain white with $1 \frac{1 / 2}{2}$ sinistral turns (Pl. I, figs. 3A-3B; Pl. II, figs. 2-3); it is always small, inclined fairly to approach a horizontal plane in the adult shell, and extended over the

1) The youngest bivalve is asymmetrical, the right valve being smaller and less inflated than the left one (Text-fig. 2, B-D). Soon the two valves become almost equal in dimension, with their umbos accentuated (Text-fig. 2, E-I). At first the protoconch stands erect to the left valve, but later it tends to be gradually inclined horizontally. A greenish adult shell may be seen when it attains the length of about $2.5-3 \mathrm{~mm}$. In this case the swelling of the umbos and the inclination tendency of the protoconch are subjected to a certain extent to an individual variation. 
right valve (Pl. I, fig. 3C; Pl. II, fig. 6). The umbos of the two valves are more or less swollen, but not so highly elevated like in Midorigai (Text-fig. 3; Pl. I,
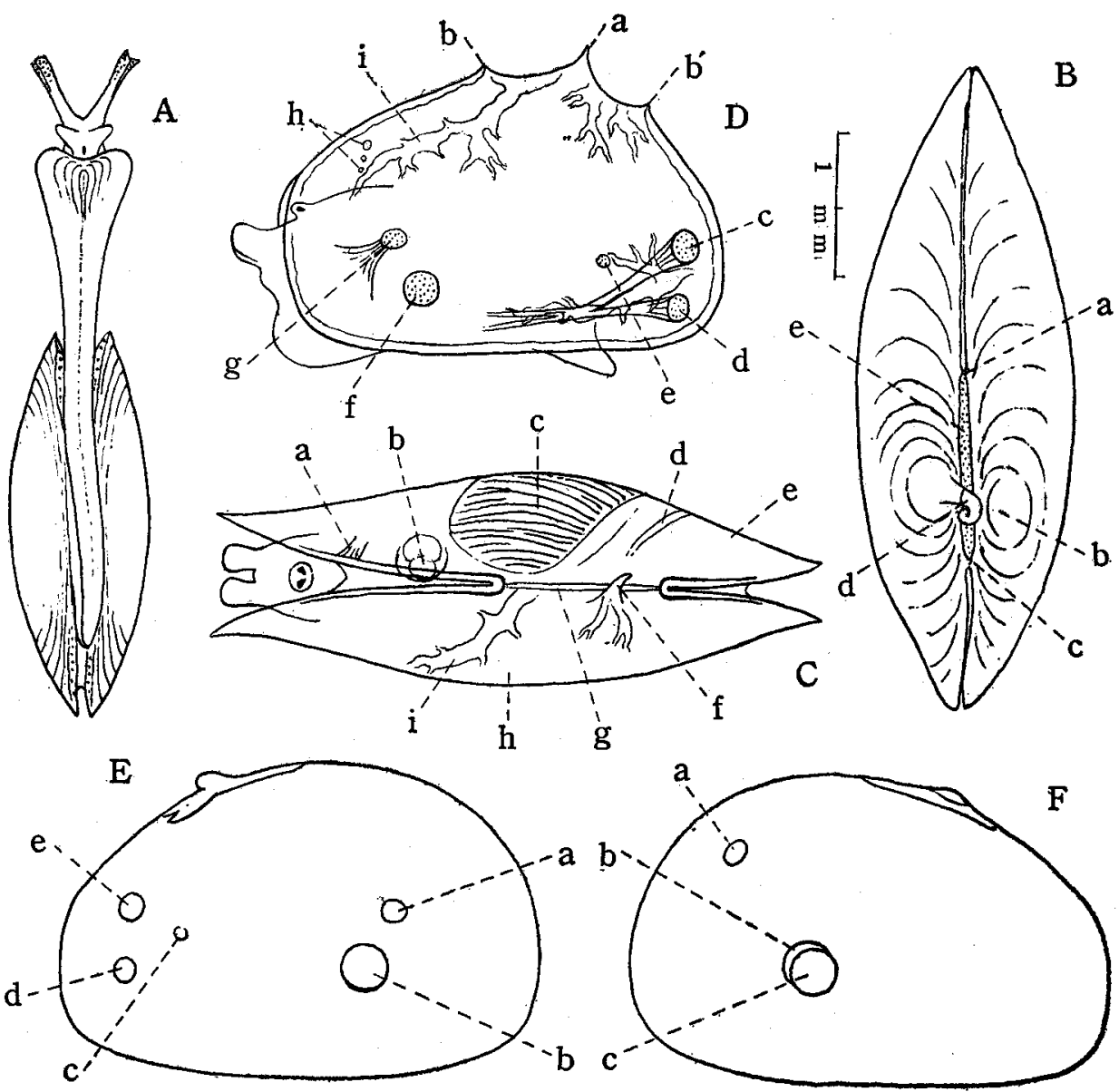

Fig. 1. Tamanovalva limax (Tamano, Inland Sea of Seto, Aug. 20, 1959). A. Ventral view of an extended animal. B. Dorsal view of a paired shell (shell-length $4.3 \mathrm{~mm}$ ). a. anterior articulation of the hinge, $b$. umbo of the right valve, c. posterior articulation of the hinge, d. protoconch of the left valve, e. ligament. C. Naked animal in a contracted state, dorsal view. a. right head retractor, b. heart, c. gill, d. "ciliated ridge", e. right mantle, f. horn of the visceral sac (h), g. median dorsal line of the visceral sac having a hinge-groove, $i$. branching sinus. $D$. Naked animal in a contracted state, left side view. $a$. horn of the visceral sac, $b-b^{\prime}$. median dorsal line of the visceral sac, c. right tail retractor, d. left tail retractor, e. transverse visceral muscle, f. adductor muscle, $g$. left foot retractor, $h$. branchings of the right head retractor, i. branching sinus. E. Left valve from inside. a. scar of the left foot retractor, b. scar of the adductor muscle, c. scar of the transverse visceral muscle, d. scar of the left tail retractor, e. scar of the right tail retractor. F. Right valve from inside. a. scar of the right head retractor, b. scar of the right foot retractor, c. scar of the adductor muscle. 
figs. 11-12). Each of the shell valves develops an elongate hinge-plate below the umbo; the hinge-plate itself is slightly sloping from the upper margin to the lower border, plain on the surface (no teeth here, see GatLIFF \& GABRIEL, 1911 ; KAWAGUTI \& BABA, 1959), and serves for the attachment of an ashy yellow ligament. The two valves are slightly articulated at the front and rear ends of the hinge as follows (Pl. I, figs. 4A-4B; Pl. II, figs. $4 \mathrm{~A}-4 \mathrm{~B}, 6 \mathrm{~A}-6 \mathrm{~B}, 7 \mathrm{~A}-7 \mathrm{~B}$; see also VERCo, 1916; HEDLEY, 1920): (1) A weak anterior cardinal to the right valve; a corresponding shallow socket to the left valve. (2) A massive posterior cardinal to the right valve; a corresponding deep socket to the left valve.

An elongate posterior cardinal to the left valve; a corresponding shallow socket to the right valve. The left and right valves are combined also by a thin periostracum which bridges over the ligament (Pl. II, fig. 8).

In shells, Edenttellina and Tamanovalva differ from each other as below (for Edenttellina, see PI. I, figs. 9A-9B, 20A-20B; Pl. II, figs. 5A-5B) :

\section{Edenttellina typica}

1. Shell very inequilateral, abruptly rounded behind.

2. Protoconch at the latter one-fourth of the shell-length.

\section{Tamanovalva limax}

1. Less inequilateral; gradually narrowed and rounded behind.

2. At the latter one-third of the shelllength.

Soft Part of Body: In the general organization of the soft part of the body, Tamanovalva is not differentiated greatly from Edenttellina. The head is bilaterally symmetrical (Pl. II, fig. 1); it has auriculate rhinophores and lobiform oral tentacles. It is notable that the paired eyes are close together in Tamanovalva (Pl. III, fig. 2), the eye-region forming a small projection on the head in the median line (cf. Oxynoe and Lobiger in Pl. IV, figs. 6, 7). Structurally these eyes are as usual in the Opisthobranchia (vesicular eyes with a large spherical lens and abundant black pigment within each of them; see also EALES, 1921). The male orifice opens on the right side of the neck, but not below the right rhinophore (P1. III, Fig. 1). The female orifice is found far back on the right wall of the visceral sac. The widely separated situation of the male and female openings represents one of the primitive features existing in the order Sacoglossa (cf. Oxynoe and Lobiger in Pl. IV, figs. 6, 7). The more striking is the presence in Tamanovalva of the external genital groove on the right of the head and neck (Pl. III, fig. 1). This groove commences from a point moderately in front of the female orifice, and runs below the male orifice as far as to the outer base of the right oral tentacle. In Tamanovalva, the genital groove, ciliated, appears to serve as an open canal for the passage of the eggs (hence it is better called the external oviducal groove ${ }^{1)}$ ). It is problematical whether the external oviducal groove in Tamanovalva may be identified with the external seminal one in many

1) Observations on the deposition by way of the external oviducal groove in Tamanovalva have been given by Dr. S. KAwAguti and Mr. T. YAMASU (1960b). 
of the lower Opisthobranchia (e. g. Bulla, Cylindrobulla, Philine, Aplysia, Dolabella, etc.). The external oviducal groove in Tamanovalva is not existing in Oxynoe and Lobiger (cf. Pl. IV, figs. 6, 7). The head and neck is fastened to the upper lateral wall of the right mantle by the right head retractor (Pl. III, fig. 1).

The Visceral Sac and the Mantle: The visceral sac, contained in the hollow of the left valve, is greatly compressed from side to side, and assumes the superficial appearance of a bivalve (Text-fig. 1, C); materially the visceral sac of Tamanovalva is asymmetrical in organization (see P1. III, figs. 3, 4; Pl. IV, figs. 1, $3,4)$. The mantle covering the visceral sac is divided into two unequal lobes; the two hung down to the level of the foot, on opposite sides of the latter. The entire margin of the mantle is double (cleft in two lappets), and it appears to produce shell substance for the growth of each of the valves. Along the median dorsal line of the visceral sac, the mantle forms a shallow depression which is designated here as a hinge-groove (Text-fig. 1, C; Pl. II, fig. 8). Beyond the length of the hinge-groove, before and behind, the bipartition of the mantle becomes gradually marked, and finally there is a mantle lobe formed on each side of the visceral mass (Text-fig. 1, C, D; Pl. III, fig. 1). A deep mantle cavity is present between the visceral mass and the right half of the mantle (Pl. III, figs. 3, 4; Pl. IV, figs. 3, 4). The gill develops as a belt of thin, longitudinal folds on the under side of the right mantle (Text-fig. 1, C; Pl. III, fig. 1; see also Pl. III, figs. 3, 4; Pl. IV, figs. 1, 3, 4). A current of fine cilia occurs on the surface of these folds. The gill in Tamanovalva is evidently homologous with that in Oxynoe and Lobiger (Pl. IV, figs. 6, 7; see also Oxynoe viridis of ELIOT, 1906 ; Lobiger serradifalci $=$ L. philipii of Pelseneer, 1894; L. souverbiei of Marcus, 1957). An osphradium is found close to the gill (Pl. III, fig. 1 ; see also Pl. III, figs. 3, 4; Pl. IV, fig. 3). It is a simple cutaneous organ covered with long cilia. As in Oxynoe and Lobiger (see Pelseneer, 1894 ; Eliot, 1906; MARCus, 1957), the kidney of Tamanovalva is contained in the interior of the right mantle (Pl. III, figs. 3, 4 ; Pl. IV, figs. 1, 3, 4). The renal cells are cubic as usual. The nephroproct opens to the mantle cavity at the latter one-third of the right mantle (Pl. III, fig. 1; Pl. IV, fig. 5). Antero-dorsally the kidney is communicated with the pericardium by a reno-pericardial canal (Pl. IV, figs. 1,2). The hypobranchial gland is behind the gill and within the right mantle in Oxynoe and Lobiger (P1. IV, figs. 6, 7; see also MARcus, 1957). In Tamanovalva, the same gland as this occurs diffusely on the surface of the visceral sac, posterior to the anus (Pl. III, fig. 1; see also Pl. III, figs. 3, 4). Each gland cell is small and flask-shaped, and produces a stream of viscid, milky fluid which takes eosin in preparations. In Tamanovalva there is a marked "ciliated ridge" running up on the rear wall of the visceral sac (Pl. III, fig. 1 ; see also Pl. III, figs. 3, 4); it passes down on the inner wall of the right mantle. A ciliary current is especially strong on the ridge. The "ciliated ridge" similar to that of Tamanovalva appears also in Oxynoe 
(Pl. IV, fig. 6), Cylindrobulla (see Ev. MARcus \& Er. MARcus, 1956) and others, but not in Lobiger. One of the most striking features in the organization of Tamanovalva is the possession of a smooth, horizontal, adductor muscle running across the former one-third of the visceral sac; the adductor muscle serves to

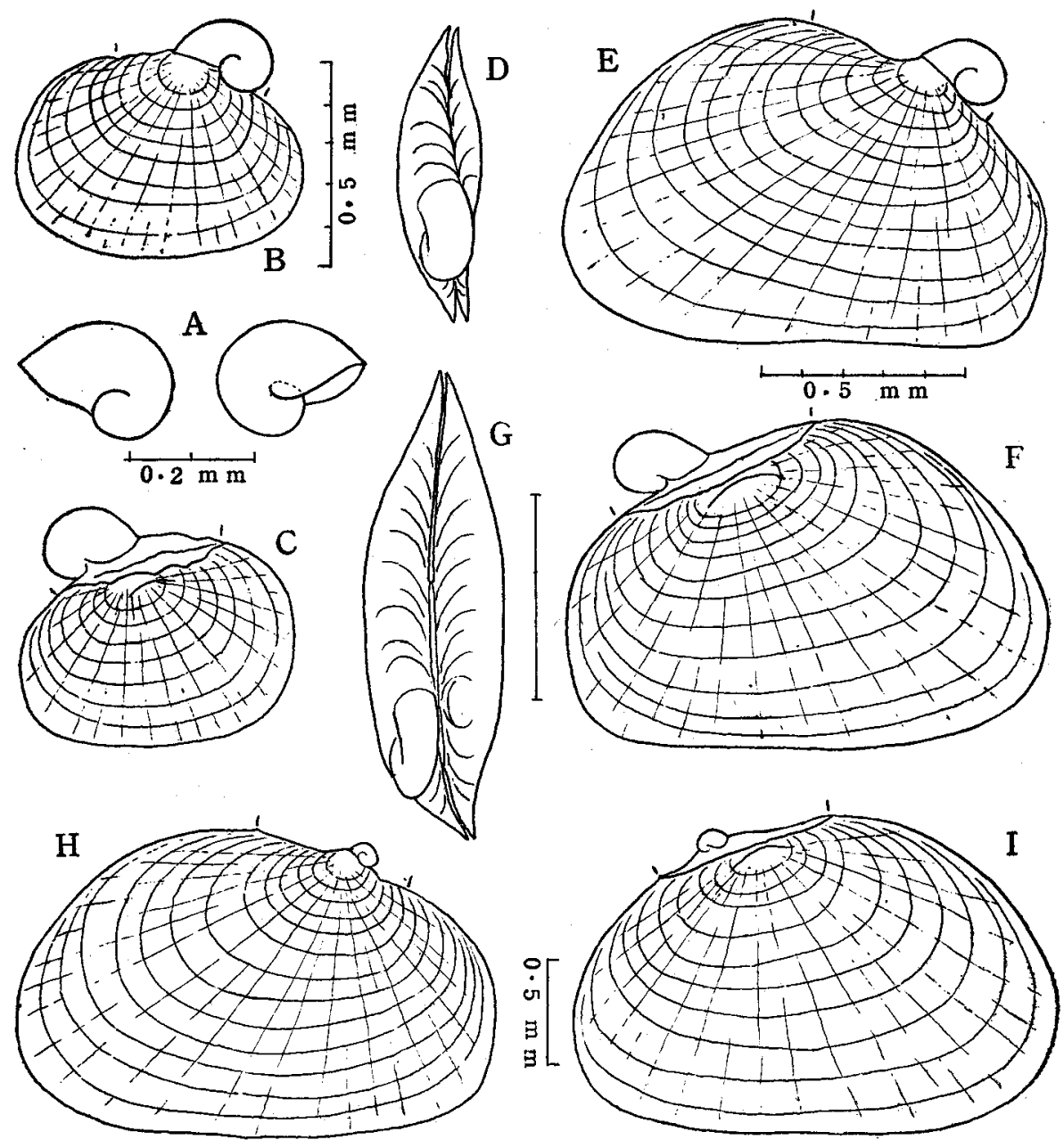

Fig. 2. Tamanovalva limax (Tamano, Inland Sea of Seto, Mar. 2, 1961). Young shells in successive stages of development. A. A veliger's shell from left and right sides. B-D. A youngest bivalve (shell-length $0.7 \mathrm{~mm}$ ) nearly in the adult form, from left, right and dorsal sides. At this stage the shell is very transparent and colourless; the soft part of the body is equally colourless excepting the brownish liver which shines through. E-G. A slightly advanced bivalve (shell-length $1.2 \mathrm{~mm}$ ). The colour is as before. H-I. A more advanced bivalve (shell-length $2.2 \mathrm{~mm}$ ). The shell is transparent and colourless as yet, but the soft part now assumes a tinge of grass-green. 
unite the left valve with its partner (Text-fig. 1, D, E, F ; Pl. III, figs. 1, 3, 4; Pl. IV, fig. 1; see also KawaGuti \& YAMASU, 1960a). A strong, oblique, adductor muscle is shown in the body of Cylindrobulla (see Ev. Marcus \& Er. Marcus, 1956).

Foot: The foot is narrow with a flat sole (Text-fig. 1, A); this latter may easily be folded longitudinally along the median line. The flask-shaped, multicellular pedal glands are thickly distributed everywhere below the ciliated epithelium of the sole. The general pedal glands are basophile, but those aggregated round the oral invagination are each specialized in having an eosinophile secretion. The tail is very short. The musculature of the foot and tail ${ }^{13}$ consists of (1) the left foot retractor, (2) the right foot retractor, (3) the left tail retractor, and (4) the right tail retractor. The left and the right ones are not strictly paired in arrangement (Text-fig. 1, D, E, F; see also Pl. III, figs. 1, 3,4 ; P1. IV, fig. 1 ).

The Nervous System: The chief ganglia composing the nervous system in Tamanovalva are identified as follows ${ }^{2)}$ (Pl. II, figs. 11, 12, 13; Pl. III, figs. 3, 4): Paired cerebro-pleural, paired pedal, paired buccal, paired parietal (infra-intestinal on the left, supra-intestinal on the right), unpaired visceral (=abdominal), unpaired osphradial, and unpaired genital ganglia. Of these the first two are centralized, and constitute a nerve ring surrounding the oesophagus. The two cerebro-pleural ganglia, dorsal to the oesophagus, are united by a commissure, and linked with the pedal granglia by a double connectives. There are no rhinophorial ganglia. The pedal ganglia on the ventral side of the oesophagus are almost completely fused together, with a fairly long parapedal commissure between the two. A statocyst is closely fixed upon each of the pedal ganglia. It contains a statolith within the cyst ciliated internally. The buccal ganglia remain as usual. The paired visceral nerve cords ( $=$ the left and the right pleurovisceral connectives) are long, and not completely untwisted (Pl. II, figs. 11, 12). The infra-intestinal ganglion is always smaller in size than the supra-intestinal. The osphradial ganglion is closely applied to the osphradium of the right mantle (Pl. II, fig. 11; Pl. III, figs. 3, 4; Pl. IV, fig. 3). The visceral ganglion occurs within the visceral sac (Pl. II, figs. 11, 12 ; Pl. III, fig. 4 ; Pl. IV, fig. 3). A small genital ganglion appears in the length of the genital nerve from the visceral ganglion. The long visceral loop thus shown above is very important in the Sacoglossa, and it demonstrates an ancestral affinity of Tamanovalva with those ranked lower in the Opisthobranchia (e.g. Actaeon, Scaphander, Bulla, etc.; see Guiart, 1901 ; Pelseneer, 1894). A somewhat streptoneurous nervous system is

1) The arrangement of the various muscles in Tamanovalva has been shown by Dr. S. KAwAGUTI and Mr. T. YAMASU (1960c).

2) See the basic pattern and modifications of the opisthobranch nervous system by GuIART, 1901 ; RUSSELL, 1929. 
recorded also from the primitive sacoglossan Arthessa (see Evans, 1950), but the account given of this is only brief. In the genera Oxynoe, Lobiger and Elysia, the chief ganglia are greatly centralized, and there is a considerable shortening of the visceral loop (for Lobiger, see PELSENEER, 1894; MARcus, 1957; for Elysia, see Russell, 1929). In a fresh specimen of Tamanovalva, the nerves are colourless, and the ganglia are yellow.

Digestive System: The digestive system in Tamanovalva is typically of the sacoglossans (Pl. II, figs. 11, 12, 13; Pl. III, fig. 3; Pl. IV, figs. 1, 3, 4), and most closely comparable with that in Oxynoe and Lobiger (for Lobiger, see PeLseneer, 1894; MARCus, 1957). The pharyngeal bulb is pear-shaped, yellowish green in life, and fastened to the latero-ventral wall of the head by a pair of retractor muscles. The radulae in Tamanovalva ${ }^{1)}$, Edenttellina, Oxynoe and Lobiger are almost alike in general configuration, differing in some points as follows (for Tamanovalva, see Pl. II, fig. 9 ; see also KAwAGUTI \& BABA, 1959; for Edenttellina, Pl. I, fig. 10; P1. II, fig. 10; for Oxynoe, refer to BABA, 1952a, 1955; for Lobiger, BABA, 1952b, 1955).

Tamanovalva limax

1. Ascending teeth $5-$ 7 , descending teeth 30-35.

2. All teeth denticulated on both edges.

3. All teeth simple at tip.
Edenttellina typica

1. Ascending 6 , descending 23 .

2. All non-denticulated, smooth.

3. Bifid at tip.
Oxynoe viridis

1. Ascending 10 , descending 22 .

2. All denticulated.

3. Simple at tip.
Lobiger sagamiensis

1. Ascending 4, descending $7,12-13$ in a heap.

2. Ascending teeth smooth, descending teeth denticulated.

3. Simple at tip.

The genera Tamanovalva, Oxynoe and Lobiger are differentiated from each other as below :

\section{Tamanovalva}

1. Pharyngeal crops paired, each elongated sac-like, internal cavity simple.

2. Salivary glands paired, each exceedingly elongated, tubular, opening by a fine duct.

3. Oesophageal diverticulum single, smooth on surface.

\section{Oxynoe}

1. A single circular crop. -

-.

2. Paired, each a villous cluster of tubules opening by a stout common duct.

3. Single, warty on surface.

In Tamanovalva, the pharyngeal crops take the form of an elongated sac with a thick muscular wall; internally they have rugose folds covered with cilia (Pl.

1) Actually the radula consists of a continuous row of teeth, but it is often seen split into two parts, the ascending and the descending (see Pl. I, fig. 6; cf. BuRN, 1960b). The total number of the teeth within a single row may vary considerably in different specimens. 
II, figs. 11, 12, 13, 14; Pl. IV, fig. 1). The whole body of the crops is slightly yellowish green. The salivary glands are colourless, hyaline and delicate (Pl. II, figs. 11, 12). They consist of an exceedingly elongated tubular gland which is faintly rugose on the surface, and a very fine duct. The wall of the glandular portion is made up of secretory cells and interstitial ones; the lumen of the tube is finely ciliated (Pl. II, fig. 15). The two salivary glands cling to the under side of the oesophageal diverticulum by their distal end. The oesophageal diverticulum, dark brown in colour, is presumably a gland, the lining epithelium of which appears to be quite uneven on the surface abutting on the central lumen (Pl. II, figs. 11, 12, 16; Pl. IV, fig. 1). The thin-walled oesophagus passes below the adductor muscle (Pl. IV, fig. 1), and then runs into the stomach (Pl. III, fig. 3 ; Pl. IV, fig. 3). The stomach forms an ill-defined chamber which receives the discharge from the liver by a number (7-8) of bile ducts in various length (Pl. III, fig. 3). Both the stomach and the bile ducts have a ciliated epithelium. The liver is well-developed. With the gonad and the genital complex, it forms a voluminous mass which fills up completely the lumen of the visceral sac (Pl. III, figs. 3, 4; Pl. IV, figs. 1, 3,4). Histologically the liver consists of cubic gland cells lining the central lumens, these latter uniting to pass into the bile ducts. In a living animal, the liver is ashy yellow with scattered black pigment. The rectum is short (Pl. III, fig. 3; Pl. IV, figs. 3, 4). It bends down towards the anus which is postero-lateral in position, as is the case with Oxynoe and Lobiger (cf. Pl. III, fig. 1; PI. IV, figs. 6, 7). The inner wall of the rectum is thickly plicate with strong cilia throughout the surface.

Circulatory System: In Oxynoe and Lobiger, the heart is largely enclosed within the mantle which overlies the visceral sac (Pl. IV, figs. 6, 7; for Lobiger, see also Pelseneer, 1894; Marcus, 1957). It is two-chambered. The belt of the gill-folds runs across the under side of the mantle, immediately behind the heart. An osphradium is accompanied by the gill. Thus the genera Oxynoe and Lobiger are literally opisthobranchiate; it is assumed that the gill in these forms comes from that in the rather extraordinary members of the Cephalaspidea (cf. Newnesia by Eliot, 1906; Cylindrobulla by Ev. Marcus \& Er. MARcus, 1956). The genus Tamanovalva is most intimately allied to Oxynoe and Lobiger in the essential characters of the heart, the gill and the osphradium. In Tamanovalva, however, the visceral sac is markedly compressed laterally, and the right mantle extends down to the level of the foot. The heart is slightly to the right of the median line, lying just below the roof of the visceral sac (Text-fig. 1, C; Pl. III, figs. 1, 5 ; Pl. IV, fig. 1). The thin-walled auricle is attached to the right mantle and receives blood from the gill. In the cross sections of a preserved specimen, the ventricle, which has a muscular wall, is on the left of the auricle, and the aorta appears to pass into the visceral sac ( $\mathrm{Pl}$. III, fig. 5). On the left wall of the visceral sac there are branching sinuses which presumably serve to carry blood 
to the gill (Text-fig. 1, C, D). The reno-pericardial canal has been given in the previous chapter on the Visceral Sac and the Mantle. There is no spacious haemocoel within the visceral sac.

Genital System: Within the order Sacoglossa, Tamanovalva appears to come nearest to Oxynoe and Lobiger, in the primitive, diaulic type of the genital apertures (see the previous chapter on Soft Part of Body; for Lobiger, see also Pelseneer, 1894; Marcus, 1957). In Tamanovalva, the ovotestis is a compact gland which lies embedded in the posterior half of the liver, slightly dorsal to the stomach on the left side (Pl. III, fig. 4; Pl. IV, fig. 4). When fresh it is colourless, and can hardly be separated from the tissue of the liver. Young individuals are protandric, but later both eggs and sperms are found in the same gland, the former extremely peripheral and the latter more internal (Pl. III, fig. 6). The ovotestis in Tamanovalva is not so differentiated into female and male acini as in Lobiger. The hermaphrodite duct develops a swollen and constricted ampulla at about half way of its length (Pl. III, fig. 6). In Lobiger, a specialized seminal vesicle is found here (Pelseneer, 1894). Distally the hermaphrodite duct bifurcates into two: the one is the vas deferens and the other the small oviduct. A voluminous prostatic gland is formed round the first part of the vas deferens (Pl. III, fig. 6; Pl. IV, fig. 4). The gland cells take eosin vividly (P1. III, fig. 7). A prostata is present also in Lobiger. After emerging from the prostata, the vas deferens passes forwards through the upper right corner of the foot (Pl. III, fig. 6; Pl. IV, figs. 1, 3); within the lumen of the head and neck it becomes free, and runs into the penis sheath (PI. III, figs. 4, 6 ; Pl. IV, fig. 1). The penis sheath is attached to the upper right wall of the neck (Pl. III, fig. 1). The penis is a short flagelliform organ showing a strong curvature at the tip (Pl. III, figs. 6,8). The vas deferens is a slender canal with internal cilia. A penis sheath is recorded also from Lobiger. The small oviduct (Pl. III, fig. 6) leads directly into the large oviduct which forms several convolutions along the entire length of it. Especially strong cilia are borne upon by the small oviduct. The external aperture of the large oviduct is the female orifice (Pl. III, fig. 6). This is found on the right wall of the visceral sac (Pl. III, figs. 1, 4; Pl. IV, fig. 4). Forming the upper right portion of the genital complex is a greatly convoluted accessory female gland which becomes fully developed when the animal is sexually matured (Pl. III, figs. 4, 6). This gland consists of two halves: the upper half is the mucous gland which stain blue with Delafielo's haematoxylin (Pl. III, fig. 6) ; the lower half, extending further behind the mucous gland, forms an albumen gland packed with coarse, eosinophile granules (Pl. III, fig. 6). The mucous gland and the albumen gland discharge into the large oviduct, close to the entrance of the small oviduct. The vagina arises from the large oviduct as a straight canal ciliated internally (PI. III, fig. 6). Distally it is communicated with a spermatheca and a spermatocyst, 
the former being decidedly larger than the latter (P1. III, fig. 6). These two vesicles are also recorded from Lobiger. In Tamanovala, there is an external oviducal groove on the right side of the head and neck (see the previous chapter on Soft Part of Body).

\section{The Affinity of the Bivalved Sacoglossans}

From the anatomical comparisons given above, it may be deduced that the mollusc Tamanovalva is most closely allied to Oxynoe and Lobiger by the similarity of the organs as follows: (1) the gill formed of thin, longitudinal folds on the under side of the right mantle; (2) the osphradium accompanied by the gill; (3) the kidney enclosed within the right mantle and situated above the gill; (4) the sacoglossan teeth with fine denticulations on both sides (Oxynoe); (5) the male orifice widely separated from the female one; $(6)$ the internal vas deferens leading directly into the penis sheath; and (7) the genitalia with two vesicles (spermatheca and spermatocyst).

But there exist a series of peculiarities distinguishing Tamanovalva from both of, or either of, the two genera, Oxynoe and Lobiger.

\section{Oxynoe Lobiger Tamanovalva}

1. With a pair of parapodia. 1. With two pairs of parapodia. 1. Without parapodia.

$\begin{array}{lll}\text { 2. Tail very long. } & \text { 2. Moderately long. } & 2 \text {. Very short. }\end{array}$

3. Without oral tentacles. 3. With oral tentacles. 3 . With oral tentacles.

4. Eyes widely separated. 4. Same as in Oxynoe. 4. Close together.

5. Without an external oviducal 5. Same as in Oxynoe. 5 . With an external oviducal groove; male orifice below groove; male orifice on right right rhinophore. side of neck.

6. Shell single, bulloid, of the 6 . Single, of the snail type, but 6 . Originally single, of the snail type. depressed and like half of a bivalve.

7. Heart slightly to the left of 7. Submedian. the median line. snail type, but later becoming bivalved.

8. Hypobranchial gland within 8. Same as in Oxynoe. the right mantle behind the gill.

7. Slightly to the right of the median line.

8. Hypobranchial gland on the postero-lateral wall of the visceral sac.

9. With a "ciliated ridge" on 9. Without a "ciliated ridge". mantle and on visceral sac posteriorly.

9. With a "ciliated ridge" on mantle and on visceral sac posteriorly.

10. Body swollen in cross sec- 10. Same as in Oxynoe. tion.

10. Greatly compressed laterally.

11. Nerve ganglia highly cen- 11. Same as in Oxynoe. tralized, visceral loop very

11. Not highly centralized, visceral loop very long. shortened. 
Within the order Sacoglossa ${ }^{1)}$, the Tamanovalvacea KAwAGUTI \& BABA, 1959 is retained here as distinct from the Oxynoacea. A brief definition of the Tamanovalvacea is given below :

With a typical sacoglossan radula. Soft part of body snail-shaped, but the visceral sac is greatly compressed from side to side; a bivalved shell, the apex of the left valve planted with a helicoid shell of the gastropod veliger. Genital orifices primitively diaulic; an external oviducal groove on the right side of the head and neck. A gill, an osphradium and a kidney approximately as in Oxynoacea. Nerve ganglia not highly centralized, having a long visceral loop.

Possibilities of the congeneric identity of Tamanovalva with Edenttellina, with Ludovicia, or further with Berthelinia, have recently been suggested. All these genera cited above resemble each other in having a bivalved shell or a helicoid protoconch at the apex of the left valve. Strictly speaking, Tamanovalva is distinct from Edenttellina in the characters of the shell and radula (see the comparison tables given previously). Based merely on the relative position of the protoconch to the shell proper, Edenttellina comes nearest to Ludovicia rather than to Tamanovalva, and this latter, in turn, may be linked with Berthelinia. But at present it is not easy to establish a certain satisfactory identification of our living animals with such fossil remains as from the Parisian Tertiary.

If all of these genera (Tamanovalva, Edenttellina, Ludovicia and Berthelinia) are to be united in a single genus, the pioneer generic name is Berthelinia; our species will be renamed as Berthelinia limax (KAwaguti \& BABA). The family name will also be changed: Bertheliniidae (=Tamanovalvidae).

The genus Berthelinia thus identified may comprise Midorigai as its congeneric member (see the comment given in the postscript). The recent species

1) The members of the Sacoglossa may have had their ancestral origin within the Cephalaspidea (possibly not within the Notaspidea; cf. ODHNER, 1934, 1939). But the anatomical features shown by the present-day sacoglossans are so varied according to the families and genera they classified in that we feel somewhat difficult in finding what the monophyletic evolution from the lower Cephalaspidea to the diversified Sacoglossa really is. A systematic synopsis of the sacoglossan suborders runs as follows:

I. Subord. Oxynoacea.

Fam. Oxynoidae. Oxynoe, Lobiger. A marked centralization of the nervous system. Shell bulloid or depressed. With parapodia. Radula and gill probably related to those in Newnesia and Cylindrobulla (Cephalaspidea). Diaulic genital orifices roughly as in Actaeon (Cephalaspidea), without an external seminal groove.

Fam. .............. Arthessa. Primitive in the somewhat streptoneurous nervous system. A bulloid shell distinct in having a posterior spout. No parapodia. A sacoglossan radula.

II. Subord. Tamanovalvacea. Primitive in the somewhat streptoneurous nervous system; specialized rather aberrantly in the bivalved shell and in the lateral compression of the body. For the other characters, see the definition of the suborder.

III. Subord. Elysiacea. Advanced in the multiform external aspects. A highly centralized nervous system. Shell disappeared. Genital orifices triaulic. 
of Berthelinia so far recorded from the world are ${ }^{1)}$ : 1. B. typica (GATLIFF \& GABRIEL, 1911) ; 2. B. corallensis (HEDLEY, 1920); 3. B. australis (BURN, 1960); and 4. B. limax (KAwAGUTI \& BABA, 1959).

The following is a concise characterization of our species from Japan ( $B$. limax):

Shell small, up to $8 \mathrm{~mm}$ in length, elongate-oval in side view, inflated and rather strongly convex, posterior end rounded, umbos at the latter one-third of the shell-length, themselves not elevated greatly; extremely thin and translucent, of a pale yellowish green or yellowish white, the surface smooth with very fine growth-lines crossed by indefinite radiating threads; periostracum colourless, pearl layer shining. The left and right valves almost equal in size, shape and convexity, combined dorsally by a faintly ashy yellow ligament over which is a contiguous layer of periostracum; each valve forming an elongated hinge-plate below the umbo; the two valves articulated at the front and rear ends of the hinge by cardinal teeth and corresponding sockets. The helicoid protoconch at the apex of the left valve small, inclined nearly horizontally, extending over the right valve. An adductor muscle scar in the anterior half of each of the valves.

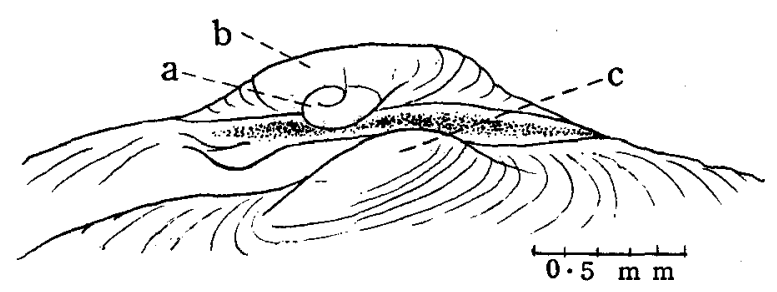

Fig. 3. Midorigai australis (Torquay, Victoria, Nov. 21, 1960, shell-length $4.6 \mathrm{~mm}$ ). Umbonal region of the paired (slightly detached) valves. a. protoconch, b. umbo of the left valve, c. umbo of the right valve!

Largest animal when fully extended, about $12 \mathrm{~mm}$ in length. Soft part of body snail-shaped, the head with auriculate rhinophores and lobiform oral tentacles; paired eyes close together, the eye-region forming a small projection on the neck in the middle line. Foot narrow, the sole flat but easily folded longitudinally along the median line; tail very short. Male orifice on the right side of the neck, female orifice far back on the right wall of the visceral sac, an external oviducal groove running below the male orifice to the outer base of the right oral tentacle. Visceral sac completely within the shell; it is greatly compressed

1) The American species and subspecies published lately are: $B$. chloris DALL, 1918 and B. c. belvederica KEEN \& SMITH, 1961. Seemingly they are closely allied to B. limax in the small and inclined [type of the] the protoconch (and finely denticulated radula teeth); they may be separated from our species by the different shape of the shell. 
from side to side. Mantle in two unequal lobes, the two hunging down to the level of the foot. Mantle-margin double (cleft in two leaflets), clinging to the border of the shell. Gill formed of thin, longitudinal folds on the under side of the right mantle; an osphradium accompanied by the gill; a kidney enclosed within the right mantle. Between the right mantle and the visceral sac there is a deep mantle cavity. Anus postero-lateral. Hypobranchial gland on the surface of the visceral sac, posterior to the anus; with a "ciliated ridge" on the rear wall of the visceral sac and on the under side of the right mantle, posterior to the gill. A horizontal adductor muscle running across the former one-third of the visceral sac. Pharyngeal bulb with paired sac-like crops and paired, exceedingly elongated, salivary glands. An oesophageal diverticulum. Radula teeth about 5-7 in the ascending series, and 30-35 in the descending spiral series; each tooth simple at tip, the blade denticulated on both edges. Liver voluminous, almost filling up the visceral sac. Nervous system roughly as in the primitive Opisthobranchia: the paired cerebro-pleural and the paired pedal ganglia are centralized round the oesophagus, the rest of the ganglia (infraintestinal, supra-intestinal and visceral) are distributed along the course of the visceral loop; a statocyst on each of the pedal ganglia. Heart two-chambered, slightly to the right of the median line. A reno-pericardial canal. A single ovotestis. Hermaphrodite duct forming an ampulla; vagina with two vesicles (spermatheca and spermatocyst); a prostate gland round the first part of the vas deferens, a penis sheath within the lumen of the head and neck, penis short flagelliform, curved at the tip, without armatures. Genital apertures primitively diaulic with male orifice and female (oviducal) orifice, vagina joined with the oviduct, vas deferens internal throughout. Body vivid grass-green almost everywhere, ornamented with opaque white dots on rhinophores, on head and on mantle-margin; grass-green colour of the mantle shining through the shell, sole paelr than body, gill-folds yellow. Mantle not red pigmented. Animal feeding on submerged green alga, Caulerpa okamurai. Distributed in the Inland Sea of Seto (common), and in Toyama Bay, Japan Sea (rare).

\section{Postscript}

1. A specimen designated as a "paratype" of Midorigai australis (Flinders, Victoria, Mar. 20, 1960) was offered by Mr. BuRN in May, 1960. It appeared then to me distinct in having smooth radula teeth; now it has been suggested by him to be identified with Berthelinia typica (GATLIFF \& GABRIEL).

2. A brief account of the Victorian specimen before me runs as follows (PI. I, figs. 9-10; Pl. II, figs. 5, 10) : the shell (about $2.5 \mathrm{~mm}$ long and $1.6 \mathrm{~mm}$ high) is elongate-oval; it is more rounded behind than in B. limax. The protoconch is small (as in limax), inclined, of $1 \frac{1 / 2}{2}$ whorls, and placed at the latter one-fourth of the shell-length, the general appearance of the shell proper being 
thus very inequilateral. The two valves are articulated as in limax. The ligament is dark brown. The umbos of the shell are not prominent. Externally the shell is pale yellowish green, and not marked with radiating, dark green bands. The soft part of the body is organized as in limax (the adductor, the male and female orifices, the external oviducal groove, etc.). The radula contains about 6 teeth in the ascending series, and 23 teeth in the descending one. All the teeth are distinctly bifid at the tip; all of them show no trace of lateral denticulations. Certainly this is referable to typica of GatlifF \& Gabriel in the shape of the shell.

3. A new form, Midorigai australis, was proposed by Mr. Burn in July, 1960. He placed 8 specimens of his collections of this species (Torquay, Victoria, Nov. $21,1960)$ at my disposal for the comparative study in January, 1961. The largest specimen (Text-fig. 3; PI. I, figs. 11-13) had the shell about $4.6 \mathrm{~mm}$ long and $2.8 \mathrm{~mm}$ high. The shell is elongate-quadrangular, inflated, of a pale yellowish green, and with broad, radiating, dark green bands showing through the transparent periostracum. The umbos are very prominent, the left umbo being greatly elevated and higher than the right one. The protoconch, situated at about the latter one-third of the shell-length, is small, and inclined completely to a horizontal plane. The two valves are articulated at the hinge as in B. limax and B. typica; they do not differ considerably in dimension from each other. The ligament is ashy brown. The radula teeth (ascending 7 , descending 35 or more) are simple at the tip and provided with distinct denticulations on each of them. The adductor muscle is single. The situation of the genital orifices, the possession of the external oviducal groove, the general musculature, and the main characters of the internal anatomy in Midorigai are essentially as given for limax (for microscopical comparisons, two young individuals of Midorigai were examined in serial transverse preparations). Now the genus Midorigai may not be maintained as different fundamentally from Berthelinia.

4. A specimen labelled as Berthelinia typica (Torquay, Victoria, Mar. 5, 1960) was presented by Mr. BURN in May, 1960. By examining the Victorian specimen, I was able to separate typica in question from our species, limax, by a series of distinctions. Unfortunately this view of mine has been neglected by Mr. BurN (cf. Burn, 1960b). Anyhow, the species typica Burn, 1960, is requested to be re-identified by itself, or in relation to typica (VERco, 1916; HedLEY, 1920), or to corallensis (HEDLEY, 1920). A short characterization of the Victorian specimen of B. typica BuRn is shown below: The shell (about $4 \mathrm{~mm}$ long and $2.6 \mathrm{~mm}$ high) is rather solid, flattened (slightly convex), and vivid yellowish green in colour. The umbos are not prominent. The general shape of the shell is almost as in typica (Verco; Hedley) and corallensis: the valves are suddenly narrowed and pointed behind. The protoconch, situated at the latter one-third of the shelllength, is very large (about twice as large as that of limax), of $1 \frac{1 / 2}{2}$ whorls, 
and nearly vertical. The articulations of the two valves appear to be well-marked. The ligament is dark brown. The radula teeth (ascending 6, descending 34) are finely denticulated; each of them is bifid at the tip. The soft part of the body is organized as in limax (the adductor, etc.).

\section{REFERENCES}

BABA, K. 1952a. Record of an ascoglossan mollusk, Oxynoe viridis (PEASE) from Sagami Bay, Japan. Venus, vol. 17, no. 2. (in Japanese)

1952b. Record of a rare sacoglossan mollusk, Lobiger (Lobiger) sagamiensis n. sp. from Sagami Bay, Japan. Zool. Mag. (Dobutsugaku Zasshi), vol. 61, no. 11. (in Japanese)

- 1955. Opisthobranchia of Sagami Bay, Supplement. Iwanami Shoten, Tokyo. (Oxynoe viridis, Lobiger sagamiensis)

BuRN, R. 1960a. A bivalve gastropod. Nature, vol. 186, no. 4719. (Edenttellina typica) 1960b. Australian bivalve gastropods. Nature, vol. 187, no. 4731. (Berthelinia typica, Midorigai australis)

Cossmann, M. 1888 (1887). Catalogue illustré des coquilles fossiles de l'Éocène des environs de Paris. Ann. Soc. Roy. Malac. Belgique, tom. 22. (Ludovicia squamula, Anomalomya corrugata, Berthelinia elegans)

Cotton, B. C. \& Godfrey, F. K. 1938. The molluscs of South Australia. Pt. I. The Pelecypoda. (Edenttellina typica)

Cox, L. R. \& REES, W. J. 1960. A bivalve gastropod. Nature, vol. 185, no. 4715. (Tamanovalva Edenttellina-Ludovicia)

Crosse, H. 1875. Description du nouveau genre Berthelinia. Journ. Conchyliol., vol. 23. (Berthelinia elegans)

Crosse, H. \& Fischer, P. 1887. Observations sur le genre Berthelinia. Journ. Conchyliol., vol. 35. (Berthelinia elegans)

DALL, W. H. 1903. Contributions to the Tertiary fauna of Florida. Trans. Wagner Free Inst. Sci. Philad., vol. 3, pt. 6. (Ludovicia squamula)

1918. Description of new species of shells chiefly from Magdalena Bay, Lower California. Proc. Biol. Soc. Wash., vol. 31. (Scintilla chloris)

EALES, N. B. 1921. Aplysia. L. M. B. C. Memoirs, 24.

Eliot, C. 1906. Nudibranchs and tectibranchs from the Indo-Pacific. II. Notes on Lophocercus, Lobiger, Haminaea, and Newnesia. Journ. Conch., vol. 11, no. 10. (Lophocercus=Oxynoe)

EVANS, T. J. 1950. A review of PEASE's genus Volvatella, together with a preliminary report on a new sacoglossan genus. Proc. Malac. Soc. London, vol. 28, pts. 2-3. (Arthessa cincta, A. elioti)

FIscher, P. 1887. Manuel de conchyliologie et de paléontologie conchyliologique. (fasc. 10, 1886, Berthelinia elegans)

GatlifF, J. H. \& Gabriel, C. J. 1911. On some new species of Victorian marine Mollusca. Proc. Roy. Soc. Victoria, vol. 24. (Edenttellina typica)

GUIART, J. 1901. Contribution a l'étude des gastéropodes opisthobranches et en particulier des céphalaspides. Mém. Soc. Zool. France, tom. 14.

Hedley, C. 1912. Descriptions of some new or noteworthy shells in the Australian Museum. Rec. Austr. Mus., vol. 8, no. 3. (Edenttellina typica)

1920. Concerning Edenttellina. Proc. Malac. Soc. London, vol. 14, pts. 2-3. (Edent. tellina typica, E. corallensis)

Kawaguti, S. 1959. Formation of the bivalve shell in a gastropod, Tamanovalva limax. Proc. Japan Acad., vol. 35, no. 10.

KAWAGUTI, S. \& BABA, K. 1959. A preliminary note on a two-valved sacoglossan gastropod, Tamanovalva limax, n. gen., n. sp., from Tamano, Japan. Biol. Journ. Okayama Univ., vol. 5, nos. 3-4. 
KAWAguti, S. \& Yamasu, T. 1959. A bivalved sacoglossan gastropod, Tamanovalva limax. Zool. Mag. (Dobutsugaku Zasshi), vol. 68, no. 12. (in Japanese)

1960a. Electron microscopic study on the adductor muscle of a bivalved gastropod, Tamanovalva limax. Biol. Journ. Okayama Univ., vol. 6, nos. 1-2. 1960b. Spawning habits of a bivalved gastroped, Tamanovalva limax. Biol. Journ. Okayama Univ., vol. 6, nos. 3-4.

1960c. Formation of the adductor muscle in a bivalvod gastropod, Tamanovalva limax. Biol. Journ. Okayama Univ., vol. 6, nos. 3-4.

KEEN, A. M. 1958. Sea shells of tropical West America. Stanford Univ. Press. (Scintilla chloris) - 1960a. A bivalve gastropod. Nature, vol. 186, no. 4722. (Tamanovalva-Edenttellina. Berthelinia)

1960b. The riddle of the bivalved gastropod. The Veliger (North. Calif. Malacozool. Club), vol. 3, no. 1. (Tamanovalva-Edenttellina-Anomalomya-Ludovicia-Berthelinia ; Julia)

Marcus, Er. 1957. On Opisthobranchia from Brazil (2). Journ. Linn. Soc. London, Zool., vol. 43, no. 292. (Lobiger souverbiei)

MARCUS, Ev. \& MARCus, Er. 1956. On the tectibranch gastropod Cylindrobulla. An. Acad. Brazil. Ci., vol. 28. no. 1 .

Mörch, O. A. L. 1876. Description d'espèces nouvelles. Journ. Conchyliol., vol. 24. (BertheliniaSpiricella)

ODHNER, N. 1934. The Nudibranchiata. British Antarctic ("Terra Nova") Expedition, 1910. Natural history report. Brit. Mus. (N. H.), Zool., vol. 7, no. 5. (Sacoglossa) 1939. Opisthobranchiate Mollusca from the western and northern coasts of Norway. Kgl. Norske Vidensk. Selsk. Skr., no. 1. (Sacoglossa)

Pelseneer, P. 1894 (1893). Recherches sur divers opisthobranches. Mém. cour. Acad. Roy. Belgique, tom. 53.

Russell, L. 1929. The comparative morphology of the elysioid and aeolidioid types of the molluscan nervous system, and its bearing on the relationships of the ascoglossan nudibranchs. Proc. Zool. Soc. London, pt. 2.

SchenK, E. T. \& McMasters, J. H. 1956. Procedure in Taxonomy, 3rd. ed.

TChang, Si. 1934. Contribution a l'étude des opisthobranches de la côte de Tsingtao. Contrib. Inst. Zool. Nat. Acad. Peiping, vol. 2, no. 2. (Bullacta exarata)

Verco, J. C. 1911. Exhibits : ...Edenttellina. Proc. Roy. Soc. South Austr., vol. 36. Austr., vol. 40.

1916. Note on Edenttellina typica GATLIFF \& GABRIEL. Trans. Roy. Soc. South

WIRZ, K. 1952. Remarques sur l'évolution du système nerveux des opisthobranches. Arch. Zool. expér. génér., tom. 88, Notes et Revue, no. 4. (not consulted)

[ ] 1960. Edenttellina typica found alive at Torquay. Austr. Newsletter, vol. 8, no. 29.

] 1960. A new bivalved gastropod from Victoria. Austr. Newsletter, vol. 8, no. 31 .

(Edenttellina typica, Midorigai australis)

The further references appeared during the press of this paper are: KEEN, A. M. 1961. High-lights of a collecting trip. The Veliger, vol. 3, no. 3; KEEN, M. A. \& SMITH, A. G. 1961. West American species of the bivalved gastropod genus Berthelinia. Proc. Calif. Acad. Sci., vol. 30, no. 2 ; SmITH, A. G. 1961. Note on the bivalved gastropod Berthelinia limax (KAWAGUTI, \& BABA, 1959). The Veliger, vol. 3, no. 3; - 1961. Notes on the habitat of Berthelinia spec. nov. from the vicinity of $\mathrm{La} \mathrm{Paz,} \mathrm{Baja} \mathrm{California,} \mathrm{Mexico.} \mathrm{Ditto} \mathrm{;} \mathrm{-} \mathrm{-} \mathrm{1961.} \mathrm{Australian}$ bivalve gastropods by Robert BURN. Ditto. 


\section{EXPLANATION OF PLATES I-IV}

\section{Piate I}

Fig.s 1-8. Tamanovalva limax.

Figs. 1A-1B. Paired valves (Tamano, Inland Sea of Seto, Aug. 20, 1959, shell-length $4 \mathrm{~mm}$ ). 1A. Left valve from outside; 1B. Right valve from outside.

Figs. 2A-2B. The same as before. 2A. Left valve from inside; 2B. Right valve from inside.

Figs. 3A-3C. Umbonal region of a paired shell (shell-length $5 \mathrm{~mm}$ ). Showing a small, inclined protoconch extending over the right valve. 3A. Protoconch from left side; 3B. Protoconch and right umbo from right side; $3 \mathrm{C}$. Protoconch and hinge from above.

Figs. 4A-4B. Hinge from inside (shell-length $4 \mathrm{~mm}$ ). 4A. Right valve; 4B. Left valve.

Figs. 5A-5B. Paired valves from inside (shell-length $7 \mathrm{~mm}$ ). Showing actual position of the various muscle scars by black spots at the corresponding places. 5A. Left valve; 5B. Right valve.

Fig. 6. Entire row of radula teeth.

Fig. 7. A youngest bivalve (shell-length $0.7 \mathrm{~mm}$ ), from left side.

Fig. 8. A slightly advanced bivalve (shell-length $1.2 \mathrm{~mm}$ ), from left side. Figs. 9-10. Edenttellina typica G. \& G.

Figs. 9A-9B. Left valve from outside and inside (Flinders, Victoria, Mar. 20, 1960, shell-length $2.5 \mathrm{~mm}$ ).

Fig. 10. Part of a radula row.

Figs. 11-13. Midorigai australis.

Fig. 11. A paired shell from right side (Torquay, Victoria, Nov. 21, 1960, shell-length $4.6 \mathrm{~mm}$ ).

Figs. 12A-12B. Hinge from inside. 12A. Right valve; 12B. Left valve. Fig. 13. Part of a radula row.

Figs. 14A-14B. Berthelinia elegans (Paris Basin Eocene, adopted from CRosse, 1875, Pl. 2, fig. 3, shell-length $0.5 \mathrm{~mm}$ ). Recorded as a gastropod. 14A. Left valve from outside; 14B. Left valve from inside.

Figs. 15A-15B. Berthelinia elegans (Paris Basin Eocene, adopted from CROSSE \& Fischer, 1887, pl. 10, figs. 1a, 1c, shell-length $1.2 \mathrm{~mm}$ ). Recorded as a bivalve. 15A. Left valve from outside; 15B. Left valve from inside. 
Figs. 16A-16B. Berthelinia elegans (Paris Basin Eocene, adopted from Cossmann, 1888, pl. 7, figs. 28-29, shell-length $2.5 \mathrm{~mm}$ ). Recorded as a bivalve. 16A. Right valve from outside; 16B. Right valve from inside.

Figs. 17A-17B. Berthelinia elegans, var. elata (Paris Basin Eocene, adopted from Cossmann, 1888, pl. 7, figs. 26-27, shell-length $2.5 \mathrm{~mm}$ ). Recorded as a bivalve. 17A. Left valve from outside; 17B. Left valve from inside.

Figs. 18A-18B. Ludovicia squamula (Paris Basin Eocene, adopted from Cossmann, 1888, pl.2, figs. 21-22, shell-length $15 \mathrm{~mm}$ ). Recorded as a bivalve. 18A. Left valve from outside; 18B. Left valve from inside.

Figs. 19A-19B. Anomalomya corrugata (Paris Basin Eocene, adopted from Cossmann, 1888, pl. 7, figs. 30-31, shell-length $5.5 \mathrm{~mm}$ ). Recorded as a bivalve. 19A. Right valve from outside; 19B. Right valve from inside.

Figs. 20A-20B. Edenttellina typica (Victoria, adopted from GatLIFF \& GABRIEL, 1911, pl. 46, fig. 6, shell-length $3 \mathrm{~mm}$ ). Recorded as a bivalve. 20A. Right valve from inside; $20 \mathrm{~B}$. Left valve from inside.

Figs. 21A-21B. Edenttellina corallensis (North Queensland, adopted from HEDLEY, 1920, figs. 7-8, shell-length $5 \mathrm{~mm}$ ). Recorded as a bivalve. 21A. Left valve from outside; 21B. Left valve from inside. 


\section{Plate II}

Figs. 1-4, 6-9, 11-16. Tamanovalva limax; Figs. 5, 10. Edentttellina typica G. \&. G.

Fig. 1. An extended animal (Tamano, Inland Sea of Seto, Aug. 20, 1959, shell-length $6 \mathrm{~mm}$, total length of animal about $10 \mathrm{~mm}$ ).

Fig. 2. Umbonal region of a paired shell (shell-length $4.5 \mathrm{~mm}$ ). Showing a small, inclined protoconch, from left side. a. protoconch, b. umbo of the right valve.

Fig. 3. The same as before, from right side

Figs. 4A-4B. Hinge from inside (shell-length $4 \mathrm{~mm}$; the same as $\mathrm{Pl}$. I, figs. 4A-4B). X. The front; $Y$. The rear. 4A. Right valve; 4B. Left valve. a. hinge-plate, b. ligament, c. protoconch, d. anterior cardinal to the right valve, e. corresponding socket to the left valve, f. posterior cardinal to the right valve, g. corresponding socket to the left valve, $h$. posterior cardinal to the left valve, i. corresponding socket to the right valve.

Figs. 5A-5B. Hinge from inside (shell-length $2.5 \mathrm{~mm}$ ). 5A. Right valve; 5B. Left valve. Letters as in Figs. 4A-4B.

Figs. 6A-6B. Hinge in the median line from above (shell-length $6 \mathrm{~mm}$ ). Showing a small, inclined protoconch extending over the right valve. $\mathrm{X}$. The front; Y. The rear. 6A. Left valve; 6B. Right valve. a. protoconch of the left valve, $b$. ligament between the left and right hinge-plates, c. anterior articulation, d. umbo of the right valve, e. posterior articulation.

Figs. 7A-7B. Hinge in the median line from below. The protoconch is hollowed to the tip. a. anterior articulation, b. posterior cardinal to the left valve $(7 \mathrm{~B})$, c. posterior cardinal to the right valve (7A).

Fig. 8. Part of the cross section of the visceral sac in about the middle of the hinge-length. a. median hinge-groove of the visceral sac, b. ligament taking eosin, c. periostracum staining with Delafield's haematoxylin. The calcareous and pearl layers of the shell are dissolved by the fixing fluid.

Fig. 9. A radula tooth $(\times 400)$.

Fig. 10. A radula tooth $(\times 750)$.

Fig. 11. Pharynx and the nervous system from a fresh specimen, in dorsal view. Slightly diagrammatized by separating the two salivary glands from each other. a. oesophagus, b. buccal ganglion, c. cerebro-pleural ganglion, d. pharyngeal crop, e. pedal ganglion, f. right pleuro-visceral connective, g. oesophageal 
diverticulum, h. supra-intestinal ganglion, i. osphradial ganglion (supplemented with serial sections), j. visceral ganglion, k. genital ganglion, 1. infra-intestinal ganglion, m. left pleurovisceral connective, n. glandular portion of the salivary gland, o. duct of the salivary gland, p. pharynx.

Fig. 12. Pharynx and the nervous system from right side. a. ascending series of radula, b. pharynx, c. mouth slit, d. descending series of radula, e. ascus, f. pharyngeal crop, g. buccal ganglion, h. pedal ganglion, i. left pleuro-visceral connective, $j$. salivary gland, k. infra-intestinal ganglion, 1. oesophagus, $m$. genital ganglion, $\mathrm{n}$. visceral ganglion, o. supra-intestinal ganglion, p. oesophageal diverticulum, q. right pleuro-visceral connective, r. cerebro-pleural ganglion.

Fig. 13. Pharynx and the nerve ring in ventral view. a. pharynx, b. ascus, c. salivary gland, d. oesophagus, e. cerebro-pleural ganglion, f. pedal ganglion, g. pharyngeal crop, h. buccal ganglion.

Fig. 14. Cross section of a pharyngeal crop $(\times 150)$.

Fig. 15. Cross section of a salivary gland $(\times 150)$. The secretory cells stain deeply with haematoxylin.

Fig, 16. Part of the wall of the oesophageal diverticulum $(\times 300)$. 


\section{Plate III}

Figs. 1-8. Tamanovalva limax.

Fig. 1. Naked animal in a contracted state, from right side. a. ventricle, b. auricle, c. right head retractor, d. penis sheath retractor, e. right foot retractor, f. eye, $g$. penis sheath, h. rhinophore, i. oral tentacle, j. external oviducal groove, $\mathrm{k}$. male orifice, 1. foot, $m$. adductor muscle, $n$. female orifice, o. tail, p. left mantle, q. anus, r. "ciliated ridge" on the left mantle, $r^{\prime}$. "ciliated ridge" on the under side of the right mantle, s. hypobranchial gland, bland, t. right mantle, u. gill-folds on the under side of the right mantle, $v$. nephroproct on the under side of the right mantle, w. osphradium within the right mantle.

Fig. 2. Cross section through the elevated eye-region $(x 130)$. a. false cornea, b. lens, c. retina.

Fig. 3. Diagrammatic representation of the digestive system in the body. All the structures are drawn in a horizontal plane. a. eye, b. cerebro-pleural ganglion, c. oesophagus, d. supra-intestinal ganglion, e. osphradial ganglion, f. osphradium, g. anus, h. hypobranchial gland, i. "ciliated ridges", j. mucous gland cells, k. right tail retractor, $\mathrm{k}^{\prime}$. left tail retractor, 1. transverse visceral muscle, m. liver, n. bile ducts, o. stomach, p. infra-intestinal ganglion, q. periostracum of the shell, r. pharynx.

Fig. 4. Diagrammatic representation of the genital system in the body. All the structures are shown in a horizontal plane. a. penis sheath, b. penis, c. right foot retractor, d. female orifice, e. gill-folds, f. kidney, g. mantle cavity, h. right mantle, i. eosinophile unicellular gland cells of the mantle margin, j. ovotestis, k. visceral ganglion, 1. adductor muscle, $m$. left foot retractor, n. head, o. rhinophore.

Fig. 5. Cross section of the visceral sac through the heart $(\times 60)$. a. pericardium, b. auricle, c. gill-folds, d. liver diverticula, e. aorta, f. ventricle.

Fig. 6. Diagrammatic representation of the genital system shown in a horizontal plane. From a matured specimen about $5 \mathrm{~mm}$ in shelllength. a. penis sheath, b. penis, c. female orifice, d. large oviduct, e. vagina, f. mucous gland, g. small oviduct, h. vas deferens, i. prostata, j. ovotestis, k. hermaphrodite duct, 1. albumen gland, m. ampulla, n. spermatocyst, o. spermatheca.

Fig. 7. Part of the prostata $(\times 120)$. a. gland cells, b. vas deferens.

Fig. 8. Cross section of the penis $(\times 230)$. 


\section{Plate IV}

Figs. 1-5. Tamanovalva limax. The serial cross sections (figs. 1, 3, 4) were prepared from a young individual about $3 \mathrm{~mm}$ in shell-length.

Fig. 1. Cross section of the body approximately along the vertical line A-A of Pl. III, fig. 1, viz.: through the middle of the adductor muscle. The head is so greatly contracted in the fixing fluid that the pharynx and the penis sheath come to overlie the adductor. a. ventricle, b. reno-pericardial canal, c. origin of the right pharyngeal crop, d. penis, e. cerebro-pleural ganglion, f. penis sheath, g. oesophageal diverticulum, $h$. origin of the right foot retractor, i. supra-intestinal ganglion, j. osphradial nerve, $k$. adductor muscle, 1 . right pleuro-visceral connective, m. vas deferens, n. aggregated pedal glands, o. oesophagus, p. left pleuro-visceral connective, q. salivary gland, r. infraintestinal ganglion, s. left pharyngeal crop, $t$. origin of the left foot retractor, $u$. pharynx, v. aorta, w. liver, $x$. periostracum of the shell.

Fig. 2. Part of the right mantle to show the reno-pericardial canal in Fig. $1(\times 300)$. a. kidney, b. gill-fold, c. reno-pericardial canal.

Fig. 3. Cross section approximately along the vertical line $\mathrm{B}-\mathrm{B}$ of $\mathrm{Pl}$. III, fig. 1, viz.: through the visceral ganglion which is immediately behind the adductor. a. gill-folds, b. rectum about to start from the stomach, c. kidney, d. accessory female gland not fully differentiated, e. mantle cavity, f. visceral ganglion, $\mathrm{g}$. osphradial ganglion, h. osphradium, i. vas deferens, j. right mantle, k. left mantle, 1. prostata, m. oesophagus about to run up into the stomach, n. ampulla, o. spermatheca, p. stomach, q. - ovotestis.

Fig. 4. Cross section approximately along the vertical line $\mathrm{C}-\mathrm{C}$ of $\mathrm{Pl}$. III, fig. 1, viz.: through the female orifice and the genital complex. a. "ciliated ridge", b. rectum, c. accessory female gland about to open into the large oviduct, d. small oviduct about to join with the large oviduct (e), f. duct of the spermatheca, g. duct of the spermatocyst (h), i. female orifice, j. genital ganglion, k. prostata, 1. ampulla, m. hermaphrodite duct, n. stomach, o. ovotestis.

Fig. 5. Part of the right mantle to show the nephroproct opening into the mantle cavity $(\times 300)$. a. renal cells, b. nephroproct. 
Fig. 6. Oxynoe viridis (Misaki, Sagami Bay, Aug. 29, 1951, total length of animal $25 \mathrm{~mm}$ ). General organization from the dorsal side. Slightly diagrammatic. a. rhinophore, b. male orifice, c. female orifice below the right mantle, d. parapodial lobes, e. osphradium within the right mantle, f. gill-folds on the under side of the right mantle, g. hypobranchial gland within the right mantle, h. anus on the right wall of the visceral sac, i. "ciliated ridge" on the under side of the right mantle, j. auricle, k. ventricle, 1. pericardium, $m$. outline of the mantle overlying the visceral sac, n. eye.

Fig. 7. Lobiger sagamiensis (Misaki, Sagami Bay, Aug. 24, 1951, total length of animal $10 \mathrm{~mm}$ ). General organization from the dorsal side. Slightly diagrammatic. a. male orifice, b. pericardium, c. osphradium, d. female orifice, e. hypobranchial gland, f. anus, g. gill-folds, h. ventricle, i. outline of the mantle, j. eye, I-II. parapodial lobes. 
Publ. Seto Mar. Biol. Lab., IX, 1 (1961)

PLATE I
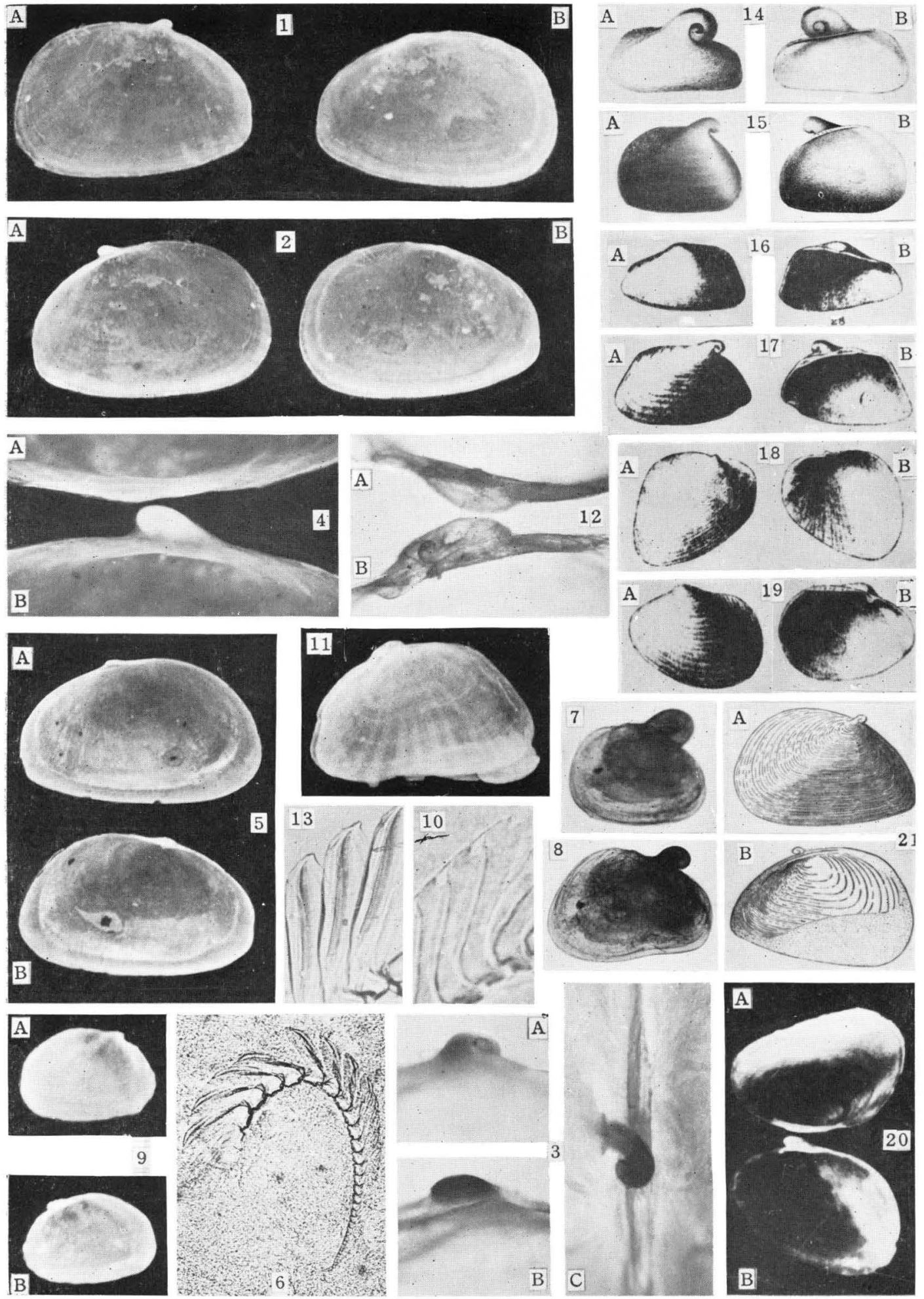

K. Baba: Identification and Affinity of Tamanovalva limax. 
Publ. Seto Mar. Biol. Lab., IX, 1 (1961)

PLATE II
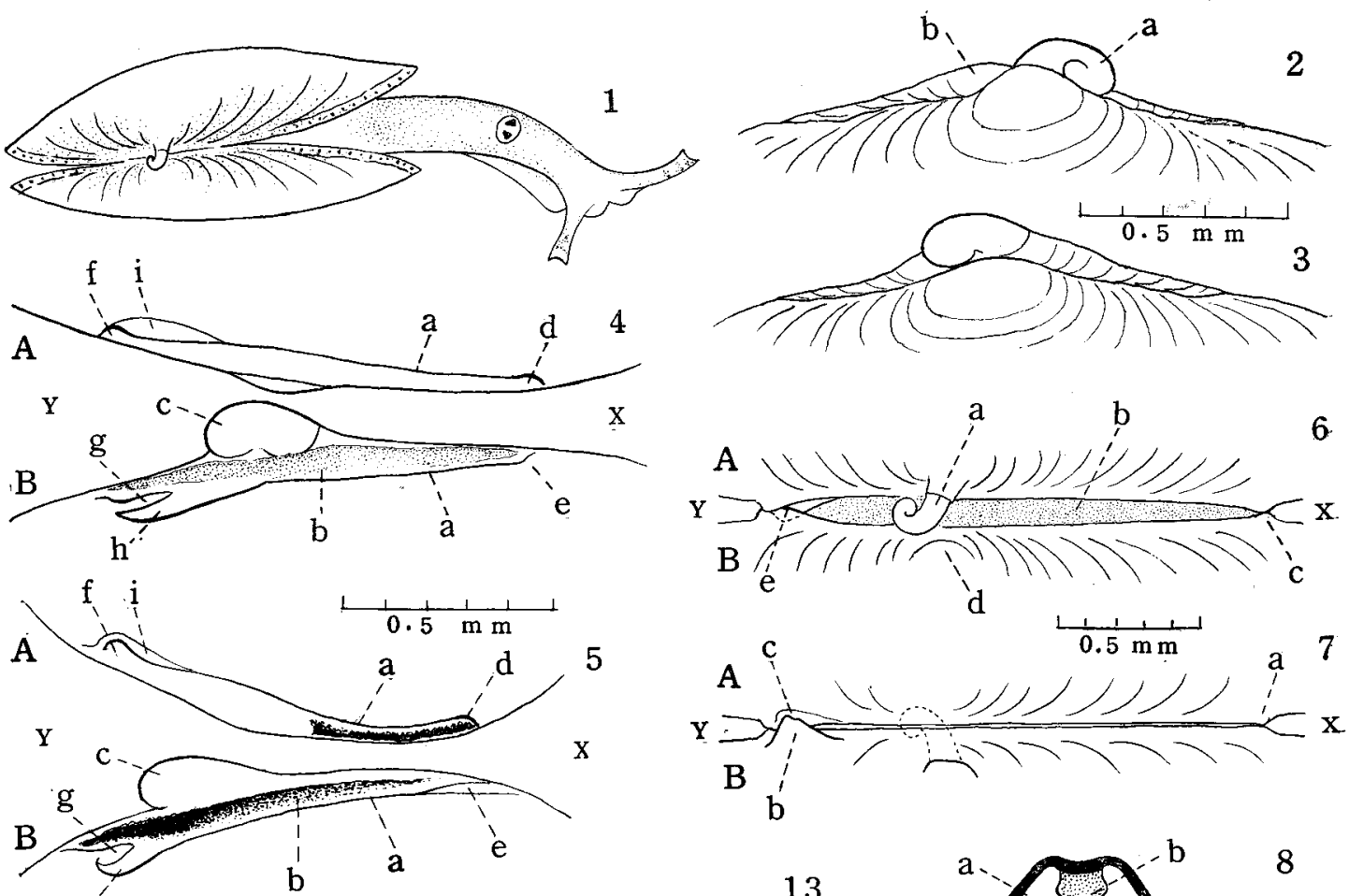

6

$\mathrm{h}^{\prime}$
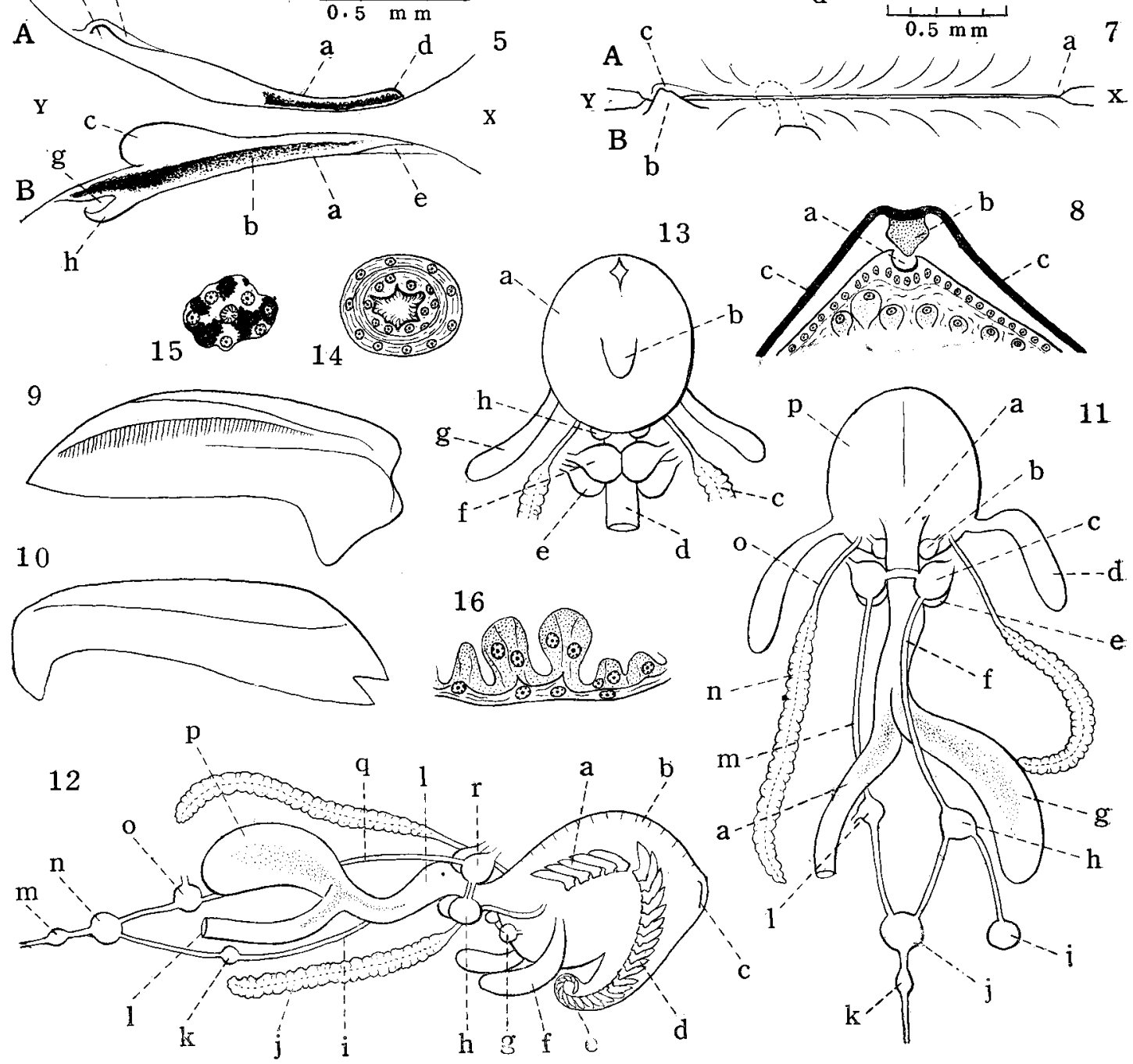

K. Baba: Identification and Affinity of Tamanovalva limax. 
Publ. Seto Mar. Biol. Lab., IX, 1 (1961)

PLATE III

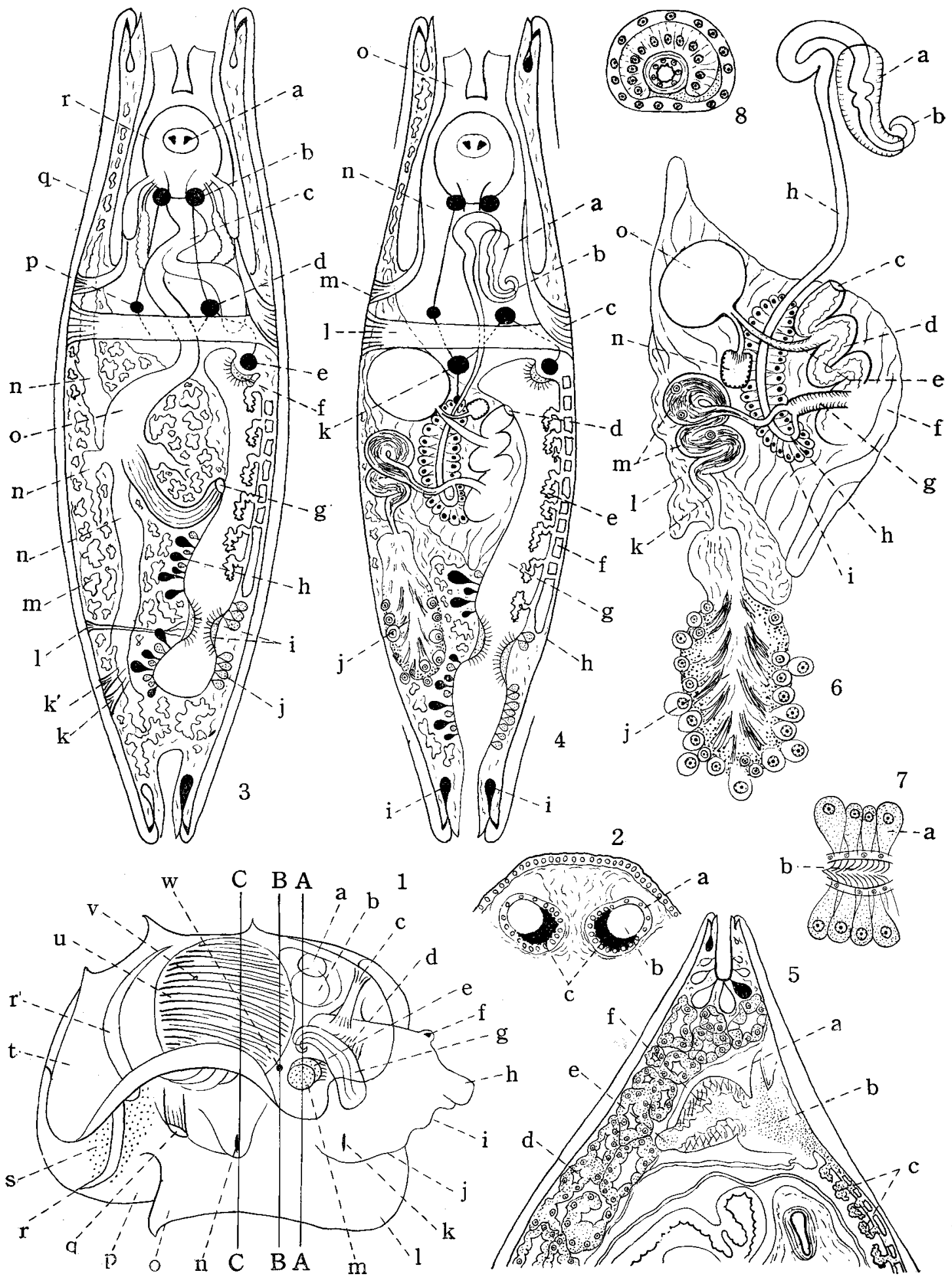

K. Baba: Identification and Affinity of Tamanovalva limax. 


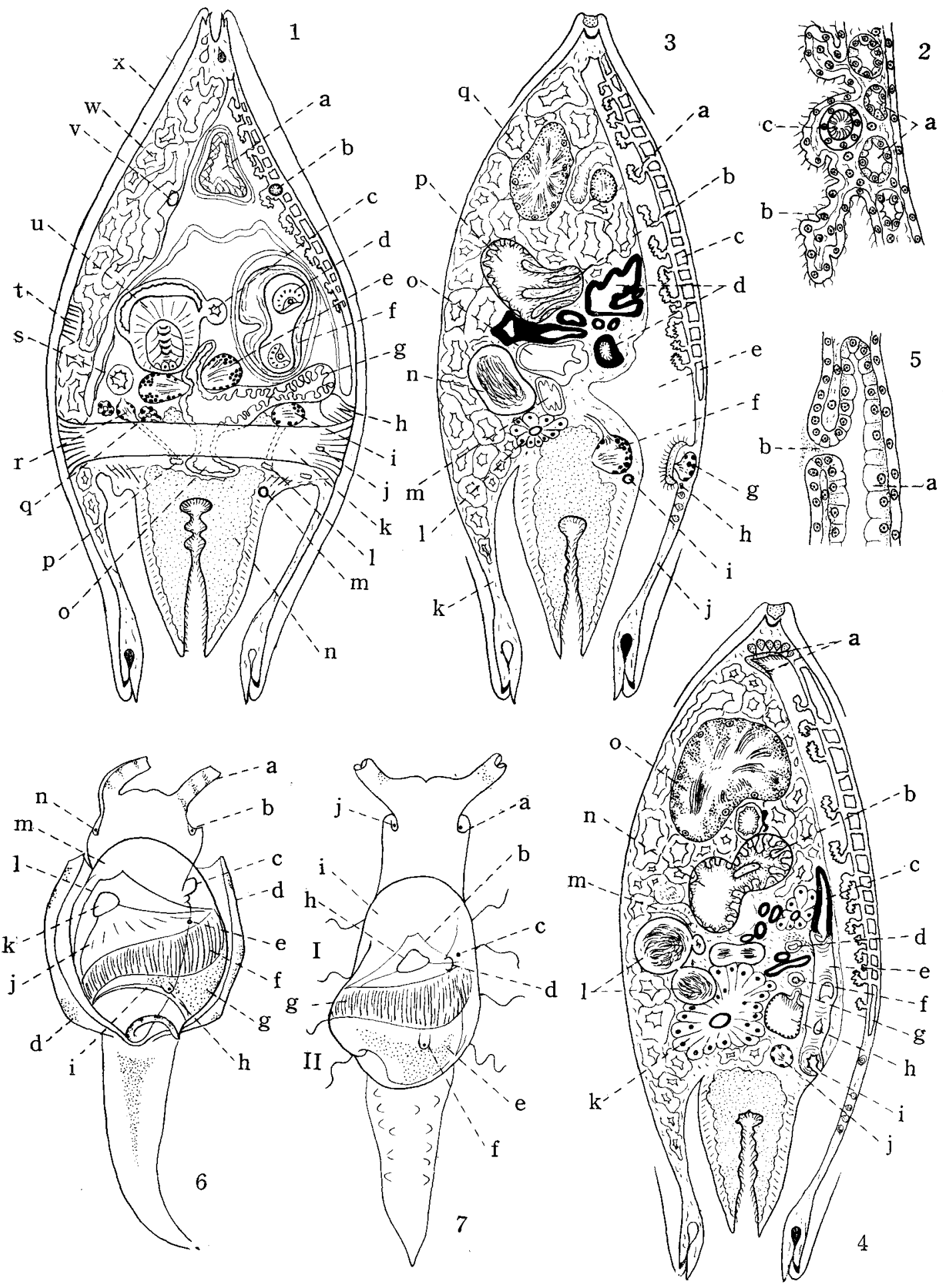

K. BABa: Identification and Affinity of Tamanovalva limax. 